\title{
Cuticular surface damage of Ascaridia galli adult worms treated with Veitchia merrillii betel nuts extract in vitro
}

\author{
Ummu Balqis ${ }^{1}$, Muhammad Hambal ${ }^{2}$, Rinidar $^{3}$, Farida Athaillah², Ismail ${ }^{4}$, Azhar ${ }^{5}$, Henni Vanda ${ }^{3}$ and Darmawi ${ }^{6,7}$ \\ 1. Laboratory of Pathology, Faculty of Veterinary Medicine, Syiah Kuala University, Banda Aceh, Aceh, Indonesia; \\ 2. Laboratory of Parasitology, Faculty of Veterinary Medicine, Syiah Kuala University, Banda Aceh, Aceh, Indonesia; \\ 3. Laboratory of Pharmacology, Faculty of Veterinary Medicine, Syiah Kuala University, Banda Aceh, Aceh, Indonesia; \\ 4. Laboratory of Veterinary Public Health, Faculty of Veterinary Medicine, Syiah Kuala University, Banda Aceh, Aceh, \\ Indonesia; 5. Laboratory of Physiology, Faculty of Veterinary Medicine, Syiah Kuala University, Banda Aceh, Aceh, \\ Indonesia; 6. Laboratory of Research, Faculty of Veterinary Medicine, Syiah Kuala University, Banda Aceh, Aceh, Indonesia; \\ 7. Laboratory of Microbiology, Faculty of Veterinary Medicine, Syiah Kuala University, Banda Aceh, Aceh, Indonesia. \\ Corresponding author: Darmawi, e-mail: darmawi@unsyiah.ac.id \\ Co-authors: UB: ummu.balqis@unsyiah.ac.id, MH: hambal.m@unsyiah.ac.id, R: rinidar@unsyiah.ac.id, \\ FA: farida_athaillah@yahoo.com, I: ismail@unsyiah.ac.id, A: azharm.dvm@gmail.com, HV: hennivanda75@unsyiah.ac.id \\ Received: 14-12-2016, Accepted: 17-05-2017, Published online: 03-07-2017 \\ doi: 10.14202/vetworld.2017.732-737 How to cite this article: Balqis U, Hambal M, Rinidar, Athaillah F, Ismail, Azhar, \\ Vanda H, Darmawi (2017) Cuticular surface damage of Ascaridia galli adult worms treated with Veitchia merrillii betel nuts \\ extract in vitro, Veterinary World, 10(7): 732-737.
}

\begin{abstract}
Aim: The objective of this research was to in vitro evaluate the cuticular surface damage of Ascaridia galli adult worms treated with ethanolic extract of betel nuts Veitchia merrillii.

Materials and Methods: Phytochemical screening was done using $\mathrm{FeCl}_{3}$, Wagner and Dragendorff reagents, NaOH, $\mathrm{MgHCl}$, and Liebermann-Burchard reaction test. Amount of 16 worms were segregated into four groups with three replicates. Four worms of each group submerged into phosphate buffered saline, $25 \mathrm{mg} / \mathrm{ml}$, and $75 \mathrm{mg} / \mathrm{ml} \mathrm{crude} \mathrm{ethanolic}$ extract of $V$. merrillii, and $15 \mathrm{mg} / \mathrm{ml}$ albendazole. The effect of these extract was observed $40 \mathrm{~h}$ after incubation as soon as worms death. The worms were sectioned transversally and were explored for any cuticular histopathological changes in their body surface under microscope.
\end{abstract}

Results: We found that the ethanolic extract of $V$. merrillii betel nuts contains tannins, alkaloids, flavonoids, triterpenoids, and saponins. The ethanolic extract of betel nuts $V$. merrillii induces surface alterations caused cuticular damage of $A$. galli adult worms.

Conclusion: We concluded that ethanolic extract of betel nuts $V$. merrillii possess anthelmintic activity caused cuticular damage of $A$. galli adult worms.

Keywords: anthelmintics, Ascaridia galli, cuticle, Veitchia merrillii.

\section{Introduction}

Infestation by intestinal roundworm Ascaridia galli called ascaridiosis presents a main threat to the indigenous poultry production in most parts of the world. Ascaridiosis is prevalent in several countries such as Egypt [1], Bangladesh [2,3], Germany [4], Jordan [5], India [6,7], Iraq [8], and Indonesia [9,10]. Heavily infected chickens may cause damaging the integrity of intestinal villi $[7,8]$, intestinal mucosal defense can be changed [10], lumen contained thick white pasty mucous, enteritis, and intestinal wall appeared to be thickened with mucosa giving a velvety appearance [7], and nutrient utilization can be show affected which decreased weight gain [11]. A. galli also affects millions of poultry resulting in considerable economic losses in domestic and farmyard bird.

Copyright: Balqis, et al. Open Access. This article is distributed under the terms of the Creative Commons Attribution 4.0 International License (http://creativecommons.org/licenses/by/4.0/), which permits unrestricted use, distribution, and reproduction in any medium, provided you give appropriate credit to the original author(s) and the source, provide a link to the Creative Commons license, and indicate if changes were made. The Creative Commons Public Domain Dedication waiver (http://creativecommons.org/ publicdomain/zero/1.0/) applies to the data made available in this article, unless otherwise stated.
A number of anthelmintic compounds have been used in controlling the parasite infected in animals.

Treatments using commercial anthelmintic drugs are not only expensive but also disadvantages such as the risk of environmental pollution, affect host health, and leads to widespread development of resistance to most of the current anthelmintics [12], for example, the existence of multiple anthelmintic resistance in gastrointestinal nematodes of sheep in Colombia [13]. Anthelmintic resistance is almost cosmopolitan in distribution in almost all species of domestic animals and even in some parasites of human beings [14]. In Punjab (Pakistan), several gastrointestinal parasites, namely, Haemonchus contortus, Trichostrongylus colubriformis, Cooperia curticei, Teladorsagia circumcincta, and Oesophagostomum spp. had resistance on oxfendazole in beetal goats [15]. The control of gastrointestinal nematodes using anthelmintic in cattle leads to the development of Cooperia punctata, Cooperia pectinata, Oesophagostomum radiatum, and Trichuris spp. population resistant to moxidectin [16]. The previous experiment reported that in some farms in the northwestern region of São Paulo State, Brazil; there are indications about the resistant of Cooperia 
spp. and Haemonchus spp., especially to ivermectin. The resistance to albendazole and levamisole was also observed in cattle [17]. Regarding the prevalence of anthelmintic resistance in gastrointestinal nematodes, Demeler et al. [18] suggested that testing of anthelmintic efficacy should be performed more intensively due to the possible insufficient efficacy of ivermectin and benzimidazole on cattle farms in Germany, Belgium and Sweden.

Because of the problems arising from the use of conventional anthelmintics highlighted above, some investigators have mentioned the importance to find alternative ethnomedicinal extracted from plant materials. Many plants species used worldwide in traditional medicine as better alternative is gaining significance. In the study of El-Sherbini and Osman [19] evaluated aqueous extracts of immature fruits of the mango Mangifera indica L. for inhibition of larval development indicate that this fruit could assist Strongyloides stercoralis control. For anthelmintic properties, in vitro and in vivo employed by Hussain et al. [20] showed that both Trianthema portulacastrum and Musa paradisiaca possess strong anthelmintic activity against Oesophagostomum columbianum, Trichuris ovis, Trichostrongylus spp., and $H$. contortus. In another study using plant Lippia sidoides; CamurÇa-Vasconcelos et al. [21] noticed that the efficacy of the $L$. sidoides essential oil on sheep gastrointestinal nematodes, $H$. contortus. The traditional system of treating parasitic diseases hold a great promise as a source of easily available effective anthelmintic agents to the people particularly in tropical developing countries, including Indonesia.

Because of easy availability, $A$. galli adult worms are used as suitable models for screening of anthelmintic drug. Various researchers observed in vitro anthelmintic effects of Bishkatali Azadirachta indica (neem) leaves extract against $A$. galli [2,3,22,23]. Regarding anthelmintic activity against $A$. galli, Ali et al. [24] reported that the parasiticidal effect of albendazole was less in comparison with saponins extracted from Teucrium stocksianum. Abdelqader et al. [25] reported that citrus peels extracts have potential anthelmintic properties against A. galli. Alrubaie [8] used the Curcuma longa L. roots alcoholic extract against worm A. galli. Ahmad et al. [6] and Salam [7] demonstrated that the effect of Mentha longifolia leaf extract might contribute to the development of effective against $A$. galli. Previously, Islam et al. [22] suggested that dust of Bishkatali (Polygonum hydropiper) leaves can be used with litter for inhibition of development of $A$. galli eggs and fresh juice and extract of $A$. indica and papaya (Carica papaya) may be impregnated in litter and used after sundry.

Veitchia merrillii betel nuts from the Palmaceae family is a tropical fruit, which is also called "Christmas Palm" because its fruits become bright scarlet and tend to be that color in winter and is widely distributed in different parts of the world. The fatty acid composition, determined by gas chromatography, rendered that palmitic, oleic, and linoleic acids were the major compounds in extracts from the $V$. merrillii species [26]. Our previously study indicated that $V$. merrillii betel nuts extract reduced motility, paralysis, and death time A. galli adult worms in vitro, is possible to be potential for developing herbal-based anthelmintic to control $A$. galli $[27,28]$. But unfortunately, the research did not show any histological alterations in their cuticle architecture after exposure to $V$. merrillii extract. It is hoped that this study may improve knowledge of the anthelmintic activity of $V$. merrillii nuts extract caused any histological alterations in the tissue of $A$. galli adult worms using light microscopy.

\section{Materials and Methods}

\section{Ethical approval}

This research was approved by the Animal Ethics Committee of Faculty of Veterinary Medicine, Syiah Kuala University (Approval No. 10/KEPH-C/ III/2016). The chickens from which $A$. galli adult worms were collected, were handled in accordance with good animal practices required by the Animal Ethics Committee and the guidelines of local rules and regulations.

\section{Extraction of $\boldsymbol{V}$. merrillii betel nuts}

$V$. merrillii betel nuts were procured from around yard areas of Banda Aceh. The plant was identified in the Herbarium, Department of Biological Sciences, Syiah Kuala University, and voucher specimen number of 63 . The betel nuts were pulverized into powder by pounding in a mortal using a pastel. The powder of betel nuts ( $250 \mathrm{~g})$ was extracted using ethanol as explained by Hussain et al. [20] and Sarojini et al. [29]. Dry powdered betel nuts material (1.5 kg) was soaked in $6 \mathrm{~L}$ of $70 \%$ aqueous (aq.) ethanol by cold maceration at room temperature for 3 days. The filtrate collected through muslin cloth by repeated soaking of dry powder of betel nuts materials. The extract was then concentrated by evaporation under a temperature $40^{\circ} \mathrm{C}$ to dryness as explained by Hussain et al. [20] and Anthikat et al. [30] with certain modification. The extract was then resuspended in distilled water and diluted to the desired concentration.

\section{Phytochemical screening}

Phytochemical screening was done for verifying tannins, alkaloids, flavonoids, saponins, terpenoids, and steroids groups present in the extract. Tannins were tested using $\mathrm{FeCl}_{3}$. Alkaloids were verified using Wagner and Dragendorff reagents. Flavonoids and saponins were determined by the $\mathrm{NaOH}$, concentrated sulfate acid, and $\mathrm{MgHCl}$ tests. Terpenoids and steroids were verified by the Liebermann-Burchard reaction as described by El-Sherbini and Osman [19], Balqis et al. [27], Hamzah et al. [28], Sarojini et al. [29], Suleiman et al. [31].

\section{Collection of $\boldsymbol{A}$. galli roundworms}

The $A$. galli roundworms acquired from intestines of native breed domestic fowl (Gallus domesticus) 
which were procured from the local chickens in Banda Aceh. The collected intestines immediately were taken to the Research Laboratory of the Faculty of Veterinary Medicine of Syiah Kuala University. All of the intestines were dissected longitudinally and submerged in normal saline solution. All worms visible to the naked eye were collected using a pair of forceps. A. galli adult worms approximately of having an average size as $5-7 \mathrm{~cm}$ were collected in and thoroughly washed with $9 \%$ neutral phosphate-buffered saline. The most robust specimens of the lot were chosen for in vitro anthelmintic activity testing as described by Balqis et al. [27], Hamzah et al. [28], Lalchhandama [32].

\section{Anthelmintic activity}

The effect of the $V$. merrillii betel nuts extract was assayed on the nematode. Amount of four A. galli adult worms placed in Petri dishes. The worms were maintained in normal saline solution. The prelabeled extracted from $V$. merrillii betel nuts were tested at concentration of 25 and $75 \mathrm{mg} / \mathrm{ml}$. We used a positive control $25 \mathrm{ml}$ albendazole (standard drug) at concentration of $15 \mathrm{mg} / \mathrm{ml}$. Meanwhile, for negative control, we used $25 \mathrm{ml}$ distilled water. All plates were incubated in a room temperature for 48-h $[24,27,28]$.

\section{Tissue preparation for histological alterations protocol}

Each roundworm procured from the Petri dishes of each group were set for paraffin embedding and were dissected for histological sections through the middle portion of the body. This process was performed for each roundworm using sterile instruments for each dissection. The middle's segment was fixed in $10 \%$ buffered normal formalin. Fixed samples were dehydrated in the ascending concentrations of ethanol $(50 \%, 60 \%, 70 \%, 80 \%, 96 \%$, and $100 \%)$. The samples were cleared in xylol and were embedded in paraffin wax. The worms were sectioned transversally using a microtome. The sections were deparaffinized with three changes of xylene (I, II, and III) for $3 \mathrm{~min}$ of each and were explored for any histopathological changes in their body surface under microscope as described by Darmawi et al. [9].

Three of each histological sections (3-5 $\mu \mathrm{m}$ of thickness) were stained with hematoxylin and eosin (pH 0.1) (Sigma). After washing, sections were counterstained with eosin and mounted with Entellan ${ }^{\circledR}$ as described by Darmawi et al. [9] and Darmawi et al. [10]. The histological alterations in the tissue of A. galli were investigated on each section under light microscopy (Olympus, Tokyo - Japan) using an eyepiece square graticule (eyepiece $10 \times$, objective $10 \times$ ), and data expressed as abnormalities and photographed as described by Jeyathilakan et al. [33], Jiraungkoorskul et al. [34], Li et al. [35], Königová et al. [36].

\section{Results}

The fraction extract from dried of $V$. merrillii betel nuts was brown greenish, semisolids with characteristic odor. The extract of $V$. merrillii betel nuts contained tannins, alkaloids, flavonoids, triterpenoids, and saponins but no steroids. Our results showed that the $A$. galli adult worms maintained in normal saline solution had a normal body wall formed by an epicuticle, cuticle, and muscle cells. We found that dramatic change in the form of disorganization and destruction of the epicuticle and cuticle of $\mathrm{A}$. galli treated with albendazole. We described that morphological changes of cuticle were observed in most of treated with $V$. merrillii betel nuts extract groups. Comparatively, the concentration of $V$. merrillii betel nuts extract $25 \mathrm{ml} / \mathrm{mg}$ showed less effect on cuticle than $75 \mathrm{mg} / \mathrm{ml}$. On the concentration of $V$. merrillii betel nuts extract $25 \mathrm{ml} / \mathrm{mg}$ we found the depletion epicuticle along with cuticle. Treatment of $A$. galli worms with $V$. merrillii betel nuts extracts $75 \mathrm{mg} / \mathrm{ml}$ resulted in dramatic changes in irregular shaped cuticle with disruption as shown in Figure-1.

\section{Discussion}

The results of this study of the fraction extract from dried of $V$. merrillii betel nuts reflect that there is no difference between our finding and previously study [26]. Tannins, saponins, alkaloids, and flavonoids of ethanolic extracts from Anogeissus leiocarpus, Khaya senegalensis, Euphorbia hirta and aqueous extracts from Annona senegalensis and Parquetina nigrescens according to Ndjonka et al. [37] affected in vitro growth and survival of nematode parasite, Caenorhabditis elegans and filarial from cattle, and Onchocerca ochengi. Indeed, tannin and flavonoid compounds extracted from unripe mango, Mangifera indica L., were able to inhibit the in vitro development

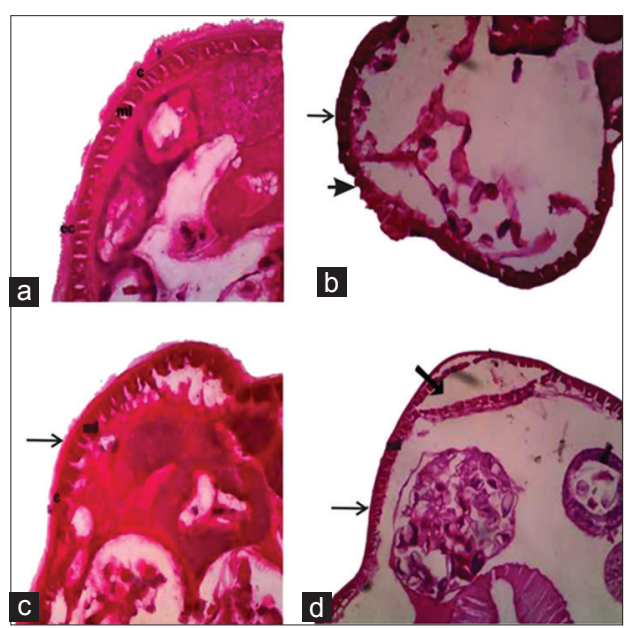

Figure-1: Photomicrograph of sections of Ascaridia galli adult worms $(\mathrm{H}$ and $\mathrm{E}, 10 \times)$. (a) Phosphate buffered saline: Appearance of epicuticle, cuticle, and muscle layer, (b) albendazole $15 \mathrm{mg} / \mathrm{ml}$ : Depletion epicuticle along with cuticle (thin arrow), damaged cuticle and muscle layer arrowhead), (c) ethanolic extract of Veitchia merrillii betel nuts $25 \mathrm{mg} / \mathrm{ml}$ : Depletion epicuticle along with cuticle (thin arrow), (d) ethanolic extract of betel nuts $V$. merrillii $75 \mathrm{mg} / \mathrm{ml}$ : Depletion epicuticle along with cuticle (thin arrow) and irregular shaped cuticle with disruption (thick arrow). ec=Epicuticle, c=Cuticle, $\mathrm{ml}=$ Muscle layer. 
of $S$. stercoralis larvae, the endemic intestinal nematode in human [19].

Our finding is a similar to those preliminary phytochemical screening observed by Balqis et al. [27] Hamzah et al. [28]. However, the mechanisms of action of these extract were not clearly understood. The study of Hassanain et al. [1] analyzed the similarity component of $A$. galli body surface. According to some investigators who observed ultrastructurally the body wall of normal $A$. galli adult worm consists of longitudinal muscle layer, syncytial hypodermis, cuticle, and epicuticle $[32,38]$. In confirmation with our early study regarding somatic of $A$. galli, we found that the cuticle contained material antigenic substances that recognized by immunoglobulin yolk antibody [9]. Previously, Oliveira-Menezes et al. [39] shown that the cuticular surface consists of transversal striations along the body of parasite filariasis in human, Wuchereria bancrofti.

In the parasitology literature, it is well known that the nematodes cuticle plays an important multi-functional role in perform protective and selective absorption function. Importantly, the cuticle of nematode becomes a primary target site of anthelmintic drugs [40]. In this study, we agree with and support those of Lalchhandama et al. [41] who found that $A$. galli adult worms treated with albendazole experiencing destruction of cuticle. A similar outcome was observed the effect anthelmintics showing transversal striations along the body in cuticular of $W$. bancrofti [39]. Previously, Robinson et al. [42] explained that albendazole had an effect on blockage of microtubules $\beta$-tubulin polymerization causes structural and functional damage in the parasite.

In vitro tests using free-living stages of parasitic helminths have been used to evaluate the anthelmintic activity of new plant compounds. Suleiman et al. [31] described that methanol extract of Cassia occidentalis and Guiera senegalensis was both positive for tannins, saponins, flavonoids, steroids, and triterpenes. Sarojini et al. [29] explained that tannins, alkaloids, flavonoids, triterpenoids, saponins, and steroids screened from Saraca indica extract displayed anthelmintic property in a dose-dependent manner against Pheretima posthuma. Ali et al. [24] found that the crude saponins prepared from $T$. stocksianum have cytotoxic and viability effect of the extract on different helminth species, namely, A. galli nematode, Raillietina spiralis cestode, and also $P$. phostuma earthworm annelida. The data presented here argue that the chemical compounds screened from $V$. merrillii betel nuts extract are also possible involved in any alterations in the cuticle architecture of the A. galli.

A characteristic surface morphology of worm alterations occurs during exposure to medicinal ethnoveterinary plant extract. This hypothesis supported by many previously reports exist about anthelmintics activity of plant extract against helminths. Alterations in the tegumental architecture of parasite Raillietina echinobothrida, the cestode of domestic fowl reported by Dasgupta et al. [43] who investigated the effect of vermicidal activity of the Acacia oxyphylla (leguminosa) stem bark-derived. The typical apoptosis resulting in cellular destruction observed in parasite $R$. echinobothrida exposed to three plant extract: Potentilla fulgens, Alpinia nigra, and Millettia pachycarpa [44]. Jeyathilakan et al. [33] reported that the trematode liver fluke Fasciola gigantica, a common parasite of the hepatic and bile ducts of herbivore mammals, i.e., buffalo, cattle, sheep, and goats showed blebbing of morphological changes in the tegument layer and breakage of spines after in vitro treated with essential oils of Cymbopogon nardus (citronella) or A. indica.

In respect of our results, the finding is a similar to those observed by Roy et al. [38], so it seems the effect of the A. oxyphylla extract induced cuticular aberrations in the regular striations and damaged epicuticle along with cuticle in $A$. galli adult worms. These findings are not different from those reported the effect of Calendula micrantha extract showing wrinkled surface with loss of striations along the body in cuticular of $A$. galli [1]. The effect of the active compound isolated from $A$. oxyphylla on the nematodes became disorganization of $A$. galli body surface [38]. In addition, the in vitro anthelmintic activity of the aqueous and hydroalcoholic extracts of Mentha longifolia against $A$. galli could be a potential alternative for treating cases of worms infections in chickens [6].

The mechanism of phytochemical constituents action to combat parasite may exhibit different modes. Lorent et al. [45] described that cytotoxic activity of saponins was able to form pores in the cell membrane may disrupt the ionic balance of the cell resulting to the cell lysis and death. Recently, the mechanism of action alkaloid extracted from Combretum zeyheri described by Nyambuya et al. [46] may be due to inhibition of transport across the cell membranes. In general, the mechanism of anthelmintics activity of plant-based extract might act by interference and combining with the cell membranes to elicit changes in cell composition. This induces membrane destabilization, change of membrane permeability, and loses of membrane potential causing the lysis of cells, which has as a consequence of damaging the cuticle. The presence of phytochemical constituents including tannins, alkaloids, flavonoids, triterpenoids, and saponins extracted from $V$. merrillii betel nuts, potentiating the anthelmintic effects in cell membranes disruption leads to cuticular damage of $A$. galli adult worms.

\section{Conclusion}

It is concluded that the in vitro experiments clearly indicate that the $V$. merrillii betel nuts extract contained tannins, alkaloids, flavonoids, triterpenoids, and saponins caused cuticular surface damage of A. galli adult worms. 


\section{Authors' Contributions}

$\mathrm{D}$ and $\mathrm{R}$ conceptualized and designed this research. The research was carried by $\mathrm{UB}, \mathrm{MH}$, and FA. The manuscript was written by D and UB. HV, A, and I finalized the manuscript. All authors read and approved the final manuscript.

\section{Acknowledgments}

Author wishes to thank the all technical staff in the Laboratory of Research, Faculty of Veterinary Medicine for their assistance. Author also thanks Ms. Muslina and Mrs. Maryam for their expert technical help in the materials preparation. Author is thankful to the Directorate General of Research and Development Strengthening Republic Indonesia, for funding of the work grant from the Hibah Bersaing (No. 019/SP2H/PP/DP2M/III/2007).

\section{Competing Interests} interests.

The authors declare that they have no competing

\section{References}

1. Hassanain, M.A., Rahman, E.H.A. and Khalil, F.A.M. (2009) New scanning electron microscopy look of Ascaridia galli (Schrank 1788) adult worm and its biological control. Res. J. Parasitol., 4: 1-11.

2. Begum, S., Mostofa, M., Alam, A.K.M., Tanjim, M., Ali, A.A.M., Islam, M.N. and Das, S. (2010) Prevalence of ascariasis and comparitave efficacy of pinapple leaves extract with patent drug piperazine against ascariasis of poultry at five villages under mymensingh district. Int. J. Biol. Res., 1(5): 41-44.

3. Saha, B.K., Abdullah-Al-Hasan, M.D., Rahman, M.A., Hassan, M.D.M. and Begum, N. (2015) Comparative eefficacy of neem leaves extract and levamisole against ascariasis in chicken. Int. J. Nat. Soc. Sci., 2: 43-48.

4. Kaufmann, F., Das, G., Sohnrey, B. and Gauly, M. (2011) Helminth infections in laying hens kept in organic free range systems in Germany. Livest. Sci., 141: 182-187.

5. Abdelqader, A., Gauly, M., Wollny, C.B. and AboShehdada, M.N. (2008) Prevalence and burden of gastro-intestinal helminths among local chickens in northern Jordan. Prev. Vet. Med., 85: 17-22.

6. Ahmad, J., Tanveer, S. and Zargar, B.A. (2013) In vitro anthelmintic activity of Mentha longifolia (L.) leaves against Ascaridia galli. Glob. Vet., 11(1): 112-117.

7. Salam, S.T. (2015) Research article ascariasis in backyard chicken-prevalence, pathology and control. Int. J. Recent Sci. Res., 6(4): 3361-3365.

8. Alrubaie, A.L. (2015) Effect of alchoholic extract of Curcuma longa on Ascaridia infestation affecting chickens. Indian J. Exp. Biol., 53: 452-456.

9. Darmawi, D., Balqis, U., Hambal, M., Tiuria, R., Priosoeryanto, B.P. and Handharyani, E. (2012) The ability of immunoglobulin yolk recognized the antigen in the tissue of Ascaridia galli. Media Peternak, 35(3): 190-195.

10. Darmawi, D., Balqis, U., Hambal, M., Tiuria, R., Frengki. and Priosoeryanto, B.P. (2013) Mucosal mast cell response in jejunum of Ascaridia galli-infected laying hens. Media Peternak, 36(2): 113-119.

11. Das, G., Kaufmann, F., Abel, H. and Gauly, M. (2010) Effect of extra dietary lysine in Ascaridia galli-infected grower layers. Vet. Parasitol., 170: 238-243.

12. Vercruysse, J., Albonico, M., Behnke, J.M., Kotze, A.C., Prichard, R.K., McCarthy, J.S., Montresor, A. and Levecke, B. (2011) Is anthelmintic resistance a concern for the control of human soil-transmitted helminths? Int. J. Parasitol Drugs Drug Resist., 1(1): 14-27.

13. Gárcia, C.M.B., Sprenger, L.K., Ortiz, E.B. and Molento, M.B. (2016) First report of multiple anthelmintic resistance in nematodes of sheep in Colombia. Acad. Bras. Ciênc., 88: 1-5.

14. Jabbar, A., Iqbal, Z., Kerboeuf, D., Muhammad, G., Khan, F.M.N. and Afaq, M. (2006) Anthelmintic resistance: The state of play revisited. Life Sci., 79: 2413-2431.

15. Saeed, M., Iqbal, Z. and Jabbar, A. (2007) Oxfendazole resistance in gastrointestinal nematodes of beetal goats at livestock farms of Punjab (Pakistan). Acta Vet., 76: 79-85.

16. Condi, G.K., Soutello, R.G.V. and Amarante, A.F.T. (2009) Moxidectin-resistant nematodes in cattle in Brazil. Vet. Parasitol., 161(3-4): 213-217.

17. Soutello, R.G.V., Seno, M.C.Z. and Amarante, A.F.T. (2007) Anthelmintic resistance in cattle nematodes in northwestern São Paulo State, Brazil. Vet. Parasitol., 148(3-4): 360-364.

18. Demeler, J., van Zeveren, A.M.J., Kleinschmidt, N., Vercruysse, J., Höglund, J., Koopmann, R., Cabaret, J., Claerebout, E., Areskog, M. and von SamsonHimmelstjerna, G. (2009) Monitoring the efficacy of ivermectin and albendazole against gastro intestinal nematodes of cattle in Northern Europe. Vet. Parasitol., 160(1-2): 109-115.

19. El-Sherbini, G.T. and Osman, S.M. (2013) Anthelmintic activity of unripe Mangifera indica L. (mango) against Strongyloides stercoralis. Int. J. Curr. Microbiol. Appl. Sci., 2(5): 401-409.

20. Hussain, A., Khan, M.N., Iqbal, Z., Sajid, M.S. and Khan, M.K. (2011) Anthelmintic activity of Trianthema portulacastrum L. and Musa paradisiaca L. against gastrointestinal nematodes of sheep. Vet. Parasitol., 179: 92-99.

21. CamurÇa-Vasconcelos, A.L.F., Bevilaqua, C.M.L., Morais, S.M., Maciel, M.V., Costa, C.T.C., Macedo, I.T.F., Oliveira, L.M.B., Braga, R.R., Silva, R.A., Vieira, L.S. and Navarro, A.M.C. (2008) Anthelmintic activity of Lippia sidoides essential oil on sheep gastrointestinal nematodes. Vet. Parasitol., 154: 167-170.

22. Islam, K.R., Farjana, T., Begum, N. and Mondal, M.M.H. (2008) In vitro efficacy of some indigenous plants on the inhibition of development of eggs of Ascaridia galli (Digenia: Nematoda). Bangladesh J. Vet. Med., 6(2): 159-167.

23. Khokon, J.U., Sharifuzzaman, Sarker, E.H., Rahman, M.A., Kisku, J.J. and Mustofa, M. (2014) Efficacy of neem leaf extract against ascariasis in indigenous chicken. Int. J. Nat. Soc. Sci., 1: 25-30.

24. Ali, N., Shah, S.W.A., Shah, I., Ahmed, G., Ghias, M. and Khan, I. (2011) Cytotoxic and anthelmintic potential of crude saponins isolated from Achillea Wilhelmsii C. Koch and Teucrium stocksianum boiss. BMC Complement. Altern. Med., 11(106): 1-7.

25. Abdelqader, A., Qaralla, B., Al-Ramamneh, D. and Das, G. (2012) Anthelmintic effects of citrus peels ethanolic extracts against Ascaridia galli. Vet. Parasitol., 188(2): 78-84.

26. Rodríguez-Leyes, E.A., Vicente-Murillo, R., GonzálezCanavaciolo, V.L., Sierra-Pérez, R.C., Marrero-Delange, D. and Leiva-Sánchez, Á.T. (2013) Contenido de ácidos grasos en la fracción lipídica de frutos de tres Arecaceae cultivadas en Cuba. Rev. CENIC Cienc. Qui Micas, 44: 23-28.

27. Balqis, U., Darmawi, Maryam, Muslina, Hamzah, A., Daud, R., Hambal, M., Rinidar, Harris, A., Muttaqien, Azhar, and Eliawardani. (2016) Motility of Ascaridia galli adult worms in vitro in ethanolic extracts of nuts Veitchia merrillii. J. Agric., 16(1): 9-15.

28. Hamzah, A., Hambal, M., Balqis, U., Darmawi, Maryam, Rasmaidar, Athaillah, F., Muttaqien, Azhar, Ismail, Rastina, and Eliawardani. (2016) In vitro anthelmintic activity of Veitchia merrillii nuts against Ascaridia galli. Tradit. Med. J., 21(2): 1-6.

29. Sarojini, N., Manjari, S.A. and Kanti, C.C. (2011) 
Phytochemical screening and anthelmintcs activity study of Saraca indica leaves extracts. Int. Res. J. Pharm., 2(5): 194-197.

30. Anthikat, R.R.N., Michael, A., Kinsalin, V.A. and Ignacimuthu, S. (2014) Antifungal activity of Areca catechu L. Int. J. Pharm. Clin. Sci., 4(1): 1-3.

31. Suleiman, M.M., Mamman, M., Sidiama, A., Ighoja, E.J., Tauheed, M. and Talba, A.M. (2014) Evaluation of anthelmintic activity of Nigerian ethnoveterinary plants; Cassia occidentalis and Guiera senegalensis. Vet. World, 7(7): 536-541.

32. Lalchhandama, K. (2010) On the structure of Ascaridia galli, the roundworm of domestic fowl. Sci. Vis., 10(1): 20-30.

33. Jeyathilakan, N., Murali, K., Anandaraj, A., Latha, B.R. and Basith, S.A. (2010) Anthelmintic activity of essential oils of Cymbopogan nardus and Azadirachta indica on Fasciola gigantica. Tamil Nadu. J. Vet. Anim. Sci., 6(5): 204-209.

34. Jiraungkoorskul, W., Sahaphong, S., Tansatit, T., Kanwanrangsan, N. and Pipatshukiat, S. (2005) Eurytrema pancreaticum: The in vitro effect of praziquantel and triclabendazole on the adult fluke. Exp. Parasitol., 111: 172-177.

35. Li, E., Zhou, P., Petrin, Z. and Singer, S.M. (2004) Mast cell-dependent control of Giardia lamblia infections in mice. Infect. Immun., 72(11): 6642-6649.

36. Königová, A., Hrckova, G., Velebný, S., Corba, J. and Várady, M. (2008) Experimental infection of Haemonchus contortus strains resistant and susceptible to benzimidazoles and the effect on mast cells distribution in the stomach of Mongolian gerbils (Meriones unguiculatus). Parasitol. Res., 102: 587-595.

37. Ndjonka, D., Agyare, C., Lüersen, K., Djafsia, B., Achukwi, D., Nukenine, E.N., Hensel, A. and Liebau, E. (2011) In vitro activity of Cameroonian and Ghanaian medicinal plants on parasitic (Onchocerca ochengi) and free-living (Caenorhabditis elegans) nematodes.
J. Helminthol., 85: 304-312.

38. Roy, B., Dasgupta, S., Manivel, V., Parameswaran, P.S. and Giri, B.R. (2012) Surface topographical and ultrastructural alterations of Raillietina echinobothrida and Ascaridia galli induced by a compound isolated from Acacia oxyphylla. Vet. Parasitol., 185: 322-326.

39. Oliveira-Menezes, A., Lins, R., Norões, J., Dreyer, G. and Lanfredi, R.M. (2007) Comparative analysis of a chemotherapy effecton the cuticular surface of Wuchereria bancrofti adult worms in vivo. Parasitol. Res., 101: 1311-1317.

40. Alvarez, L.I., Mottier, M.L. and Lanusse, C.E. (2007) Drug transfer into target helminths parasites. Trends Parasitol., 23: $97-104$

41. Lalchhandama, K., Roy, B. and Dutta, B.K. (2009) Anthelmintic activity of Acacia oxyphylla stem bark against Ascaridia galli. Pharm. Biol., 47(7): 578-583.

42. Robinson, M.W., McFerran, N., Trudgent, A., Hoey, L. and Fairweather, I. (2004) A possible model of benzimidazole binding to $ß$-tubulin disclosed by invoking an inter-domain movement. J. Mol. Graph. Model., 23: 275-284.

43. Dasgupta, S., Roy, B. and Tandon, V. (2010) Ultrastructural alterations of the tegument of Raillietina echinobothrida treated with the stem bark of Acacia oxyphylla (Leguminosae). J. Ethnopharmacol., 127: 568-571.

44. Giri, B.R., Roy, B. and Babu, S.P.S. (2013) Evidence of apoptosis in Raillietina echinobothrida induced by methanolic extracts of three traditional medicinal plants of Northeast India. Exp. Parasitol., 134: 466-473.

45. Lorent, J.H., Quetin-Leclercq, J. and MingeotLeclercq, M.P. (2014) The amphiphilic nature of saponins and their effects on artificial and biological membranes and potential consequences for red blood and cancer cells. Org. Biomol. Chem., 12: 8803-8822.

46. Nyambuya, T., Mautsa, R. and Mukanganyama, S. (2017) Alkaloid extracts from Combretum zeyheri inhibit the growth of Mycobacterium smegmatis. BMC Compl. Altern. Med., 17(124): 1-11. 